\title{
HUKUM INDUSTRI DALAM ISLAM YANG DI TERAPKAN DI DALAM EKONOMI SYARIAH
}

\author{
Muhajra Jasfar \\ Program Study Perbankan Syariah, Fakultas Ekonomi dan Bisnis Islam, \\ Universias Islam Negeri Alauddin Makassar \\ E-mail : muhajrahjfr@gmail.com
}

\begin{abstract}
Islam is a religion whose rahmatan lil'alamin does not only regulate matters of worship, but also covers all aspects of human life. Humans are legal subjects as well as unique and prospective economic actors, with the development of all needs from all industrial sectors as Muslims are required to be within the framework of sharia rules, namely halal and ethical frameworks, namely thayib. So the development of the halal industry, especially in Indonesia, is very interesting and progressive, so it is necessary to continue to be monitored within the framework of maqashid sharia. Therefore, the value of benefits and its development produces high economic value for the development of the country as well as a blessing because it is based on sharia.
\end{abstract}

Keywords: maqashid Sharia, Industry, Halal

\begin{abstract}
Abstrak
Islam merupakan agama yang rahmatan lil'alamin bukan hanya mengatur urusan ibadah saja, tetapi hingga seluruh aspek kehidupan manusia. Manusia merupakan subjek hukum sekaligus sebagai pelaku ekonomi yang unik dan prospektif, dengan berkembangnya segala kebutuhan dari segala sektor industri sebagai muslim dituntut berada dalam kerangka aturan syariah yaitu halal dan kerangka etika yaitu thayib. Maka perkembangan industri halal khususnya di Indonesia menjadi sangat menarik dan bersifat progresif, sehingga perlunya terus diawasi dalam kerangka maqashid syariah. Oleh karena itu, nilai manfaat dan perkembangannya menghasilkan nilai ekonomi yang tinggi untuk pembangunan negara juga berkah karena berdasarkan syariah.
\end{abstract}

Kata Kunci: maqashid Syariah, Industri, Halal 


\section{PENDAHULUAN}

Dunia industri terus berkembang dinamis dan persaingan yang begitu ketat semakin meningkatkan kesadaran para pelaku bisnis. Industry sangat dianjurkan dalam Islam, karena industry adalah manifestasi dari kerja keras yang sangat dianjurkan oleh Islam. Usaha industry adalah salah satu bentuk pekerjaan yang sangat dihormati dalam Islam. Namun dalam berindustri, seorang muslim harus menepati aturan-aturan Islam, agar tidak menyimpang dari tujuan Islam. Lima prinsip seorang muslim dalam aktifitas ekonominya, yaitu: tauhid uluhiyyah, tauhid rububiyah, istikhlaf, tazkiyatu 1 nafs dan al-falah.

Dalam kaitannya dengan nasionalisme, Islam mengatur bahwa industry yang menyangkut kepentingan negara dan orang banyak, maka industry tersebut harus dimiliki orang banyak dan tidak boleh dimilki pribadi bahkan hak yang diberikan Negara kepada swasta untuk bidangbidang yang menyangkut hajat hidup orang banyak dapat ditarik kembali dan kembali dikuasai Negara untuk kepentingan masyarakat jika perusahaan swasta tersebut merugikan masyarakat. Begitu juga petanian yang menjamin pangan masyarakat, maka Negara bertanggungjawab atas keberhasilan dunia pertanian. Tidak boleh ada yang dirugikan, baik pertanian maupun industry, keduanya bisa berjalan bersama dan saling mendukung. Indonesia negara yang kaya dari sisi sumber daya manusia maupun sumber daya alam sebagai anugerah dari Allah SWT. Potensi yang besar tersebut sangat berpengaruh terhadap perkembangan industri di Indonesia baik industri pariwisata, sandang, papan, pangan, dan obatobatan. Dengan jumlah penduduk mayoritas muslim di Indonesia menjadikan standar dalam peminatan sektor industri halal dari berbagai macam aspek menjadi meningkat. Peningkatan minat terhadap sektor industri halal di Indonesia tersebut merupakan bagian dari komitmen keislaman yang harus senantiasa ada dalam kehidupan sehari-hari seorang muslim.

\section{PEMBAHASAN}

Istilah industri berasal dari bahasa latin, yaitu industria yang artinya buruh atau tenaga kerja. Istilah industri sering digunakan secara umum dan luas, yaitu semua kegiatan manusia untuk memenuhi kebutuhan hidupnya dalam rangka mencapai kesejahteraan. Definisi Industri menurut Sukirno adalah perusahaan yang menjalankan kegiatan ekonomi yang tergolong dalam sektor sekunder Kegiatan itu antara lain adalah pabrik tekstil, pabrik perakitan dan pabrik 
pembuatan rokok. Industri merupakan suatu kegiatan ekonomi yang mengolah barang mentah, bahan baku, barang setengah jadi atau barang jadi untuk dijadikan barang yang lebih tinggi kegunaannya.

Secara umum pengertian industri adalah suatu usaha atau kegiatan pengolahan bahan mentah atau barang setengah jadi menjadi barang jadi barang jadi yang memiliki nilai tambah untuk mendapatkan keuntungan. Usaha perakitan atau assembling dan juga reparasi adalah bagian dari industri. Hasil industri tidak hanya berupa barang, tetapi juga dalam bentuk jasa.

Industri adalah salah satu manifestasi dari kerja keras. Dan industry adalah cabang ekonomi yang tingkat perkembangan produktivitasnya lebih cepat dari perkembangan tingkat produktivitas keseluruhan perekonomian.2 Maka peranannya dalam menciptakan produksi nasional dan menciptakan kesempatan kerja lebih besar dari peranan keseluruhan cabang ekonomi.

Maka industry menjadi asas ekonomi yang paling penting. Pada masa lalu industry hanya terbatas pada industry tradisional. Namun ketika manusia mendapatkan cara menggunakan uap dalam menjalankan mesin, maka mulailah industry mekanis menggantikan industry manual

Istilah industri berasal dari bahasa latin, yaitu industria yang artinya buruh atau tenaga kerja. Istilah industri sering digunakan secara umum dan luas, yaitu semua kegiatan manusia untuk memenuhi kebutuhan hidupnya dalam rangka mencapai kesejahteraan.

Kesimpulannya bahwa industri adalah kegiatan yang mengolah bahan mentah, bahan baku, barang setengah jadi atau barang jadi menjadi barang dengan nilai tinggi dan mempunyai nilai tambah untuk penggunaannya.

Golonganindustri berdasarkan jumlah tenaga kerja yaitu:

a. Industri besar menggunakan jumlah tenaga kerja antara 100 orang/lebih.

b. Industri sedang menggunakan jumlah tenaga kerja antara 20-99 orang.

c. Industri kecil menggunakan jumlah tenaga kerja antara 5-19 orang.

d. Industri rumah tangga menggunakan jumlah tenaga kerja 1-4 orang.

Skala Usaha sesuai dengan kriteria yang tercantum pada UU No. 20 Tahun 2008 sebagai berikut: 
a. Usaha Mikro (UMK), omset/tahun Rp0-Rp300 juta; asset Rp0-Rp50 juta.

b. Usaha Kecil (UK), omset/tahun $>$ Rp300juta $\leq \mathrm{Rp} 2,5 \mathrm{M}$; asset $>$ Rp50 juta $\leq$ Rp500juta.

c. Usaha Menengah (UM), omset/tahun $>$ Rp2,5M $\leq \mathrm{Rp} 50 \mathrm{M}$; asset $>$ Rp500 juta $\leq$ Rp10M.

d. Usaha Besar (UB), omset/tahun $>$ Rp50M; asset >Rp10M.

- Macam-macam industry Adapun klasifikasi industri berdasarkan kriteria masing-masing adalah sebagai berikut:

- Klasifikasi industri berdasarkan bahan baku

1. Industri ekstaktif, yaitu industri yang bahan bakunya diperoleh langsung dari alam, misalnya industri pertanian, perikanan dan kehutanan.

2. Industri non ekstraktif, yaitu industri yang mengolah lebih lanjut hasil industri lain. Misalnya, industri kayu lapis dan industri kain.

3. Industri fasilitatif, yaitu kegiatan industri yang menjual jasa seperti angkutan dan lain-lain.
- $\quad$ Klasifikasi industri berdasarkan tenaga kerja Menurut Biro Pusat Statistik (BPS),pengelompokkan industri berdasarkan tenaga kerja ini dibedakan menjadi 4 yaitu:29

1. Perusahaan atau industri besar, yaitu industri dengan jumlah tenaga kerja lebih dari 100 orang atau lebih. Ciri industri besar adalah memiliki modal yang besar yang dihimpun dalam bentuk pemilikan saham, tenaga kerja memiliki keterampilan khusus, dan pimpinan dipilih melalui uji kemampuan dan kelayakan. Misalnya industri tekstil.

2. Perusahaan atau industri sedang, yaitu industri yang tenaga kerjanya berjumlah 20- 99 orang.

3. Perusahaan atau industri kecil, yaitu industri yang tenaga kerjanya berjumlah sekitar 5- 19 orang. Cirinya yaitu memiliki modal yang relatif kecil, tenaga kerjanya masih terbatas. Misalnya industri batu bata dan lain-lain. 
4. Industri kerajinan Rumah Tangga, yaitu industri yang menggunakan tenaga kerja kurang dari 4 orang (termasuk tenaga kerja yang tidak dibayar). Ciri industri ini adalah memiliki modal yang sangat terbatas, tenaga kerja yang berjumlah empat orang atau kurang dari empat orang, tenaga kerja berasal dari anggota keluarga, dan pemilik atau pengelola industri biasanya kepala rumah tangga itu sendiri atau anggota keluarganya, misalnya industri makanan ringan.

Adapun hukum industry

UNDANG-UNDANG TENTANG

PERINDUSTRIAN.

Pasal 1

Dalam Undang-Undang ini yang dimaksud dengan:

1. Perindustrian adalah tatanan dan segala kegiatan yang bertalian dengan kegiatan industri.

2. Industri adalah seluruh bentuk kegiatan ekonomi yang mengolah bahan baku dan/atau memanfaatkan sumber daya industri sehingga menghasilkan barang yang mempunyai nilai tambah atau manfaat lebih tinggi, termasuk jasa industri.

3. Industri Hijau adalah Industri yang dalam proses produksinya mengutamakan upaya efisiensi dan efektivitas penggunaan sumber daya secara berkelanjutan sehingga mampu menyelaraskan pembangunan Industri dengan kelestarian fungsi lingkungan hidup serta dapat memberikan manfaat bagi masyarakat.

4. Industri Strategis adalah Industri yang penting bagi negara dan yang menguasai hajat hidup orang banyak, meningkatkan atau menghasilkan nilai tambah sumber daya alam strategis, atau mempunyai kaitan dengan kepentingan pertahanan serta keamanan negara dalam rangka pemenuhan tugas pemerintah negara.

5. Bahan Baku adalah bahan mentah, barang setengah jadi, atau barang jadi yang dapat diolah menjadi barang setengah jadi atau barang jadi yang mempunyai nilai ekonomi yang lebih tinggi.

6. Jasa Industri adalah usaha jasa yang terkait dengan kegiatan Industri. 
7. Setiap Orang adalah orang perseorangan atau korporasi.

8. Korporasi adalah kumpulan orang dan/atau kekayaan yang terorganisasi, baik merupakan badan hukum maupun bukan badan hukum.

9. Perusahaan Industri adalah Setiap Orang yang melakukan kegiatan di bidang usaha Industri yang berkedudukan di Indonesia. .

10.Perusahaan Kawasan Industri adalah perusahaan yang mengusahakan pengembangan dan pengelolaan kawasan Industri.

11.Kawasan Industri adalah kawasan tempat pemusatan kegiatan Industri yang dilengkapi dengan sarana dan prasarana penunjang yang dikembangkan dan dikelola oleh Perusahaan Kawasan Industri.

12. Teknologi Industri adalah hasil pengembangan, perbaikan, invensi, dan/atau inovasi dalam bentuk teknologi proses dan teknologi produk termasuk rancang bangun dan perekayasaan, metode, dan/atau sistem yang diterapkan dalam kegiatan Industri.

13. Data Industri adalah fakta yang dicatat atau direkam dalam bentuk angka, huruf, gambar, peta, dan/atau sejenisnya yang menunjukkan keadaan sebenarnya untuk waktu tertentu, bersifat bebas nilai, dan belum diolah terkait dengan kegiatan Perusahaan Industri.

14. Data Kawasan Industri adalah fakta yang dicatat atau direkam dalam bentuk angka, huruf, gambar, peta, dan/atau sejenisnya yang menunjukkan keadaan sebenarnya untuk waktu tertentu, bersifat bebas nilai, dan belum diolah terkait dengan kegiatan Perusahaan Kawasan Industri.

15. Informasi Industri adalah hasil pengolahan Data Industri dan Data Kawasan Industri ke dalam bentuk tabel, grafik, kesimpulan, atau narasi analisis yang memiliki arti atau makna tertentu yang bermanfaat bagi penggunanya.

- Perkembangan dan Ruang Lingkup Industri Halal di Indonesia

Potensi bisnis industri halal di dunia sangat besar. Saat ini berbagai negara, baik negara muslim maupun non-muslim berlomba-lomba menggarap potensi bisnis syariah. Berdasarkan laporan Global Islamic Economy Report 2016/2017 nilai belanja makanan dan gaya hidup (food and lifestyle sector expenditure) Muslim di sektor halal dunia mencapai US\$1,9 triliun pada tahun 2015 dan diperkirakan akan 
naik menjadi US\$ 3 pada tahun 2021.

Global Islamic Economy Report

2016/2017 menempatkan Malaysia, United

Arab Emirates dan Bahrain secara

berurutan di peringkat teratas sebagai

negara yang paling berkembang dalam

industri halal di dunia.

Dalam Global Islamic Economy Report

2016/2017 Indonesia menempati posisi 10, jauh tertinggal dari Malaysia yang berada di posisi pertama. Dari berbagai indikator yang ada, Indonesia dinilai kuat di bidang travel halal di mana pemerintah berperan aktif dalam mempromosikan hal tersebut. Namun di bidang lainnya dinilai relatif kuat. Tentu hal ini perlu menjadi perhatian kita bersama. Indonesia sebagai negara penduduk Muslim terbesar di dunia yang dikaruniai dengan berbagai sumber daya alam seharusnya bisa menjadi pemain utama di kancah nasional dan internasional khususnya di bidang industri halal

Adapun ruang lingkup dalam industri halal di Indonesia berdasarkan UU No 33 tahun 2014 tentang Jaminan Produk Halal, adalah:

a. Makanan dan Minuman

b. Obat-obatan

c. Kosmetik,

d. Produk kimiawi

e. Produk biologi

f. Produk rekayasan genetic, g. Barang gunaan yang dipakai, digunakan atau dimanfaatkan oleh masyarakat

- Analisis Maqashid Syariah dalam Pengembangan Hukum Industri Halal di Indonesia

Ulama menegaskan bahwa hukum Islam diciptakan untuk mewujudkan kemaslahatan manusia di dunia dan akirat. Kemaslahatan ada yang besifat primer (dharûriyyah), sekunder (hajiyyah), dan ada yang bersifat tersier (tahsiniyyah), sebagaimana dinyatakan Imam alGhazalî dan alSyâthibî. Menurut Imam alSyâthibî, tugas syariah berorientasi pada terwjudnyatujuantujuan kemanusiaan yang terdiri atas bagian primer (dharûriyyah), sekunder (hajiyyah), dan tersier (tahsiniyyah). Primer, artinya sesuatu yang harus ada guna terwujudnya kemaslahatan agama dan dunia. Apabila sesuatu itu hilang, kemaslahaan manusia akan sulit terwujud, bahkan akan menimbulkan kerusakan, kekacauan dan kehancuran (Ali: 2016).

Di sisi lain, kebahagiaan dan kenikmatan akan lenyap dan kerugian yang nyata akan muncul. Untuk menjaga hal tersebut diperlukan dua hal. Pertama, sesuatu yang dapat 
menjaga dan mengukuhkan pondasi

dan kaidah syariat dan merupakan

aspek utama untuk menjaga

keberadaan syariat. Kedua, sesuatu

yang dapat mencegah pelanggaran

langsung atau tidak langsung terhadap

syariat dan merupakan aspek untuk menghindari kepunahan syariat. Imam

al-Qarâfî̀ menambahkan komponen ke enam, yaitu kehormatan yang sering disebut sebagai harga diri. Oleh karena itu syariat mengharamkan fitnah atau menuduh berzina (qadzaf), membicarakan aib orang lain (ghibah).

Menurut Imam al-Syâthibî, kemaslahatan yang bersifat sekunder adalah segala hal yang dibutukan untuk memberikan kelonggaran dan mengurangi kesulitan yang biasanya menjadi kendala dalam mencapai tujuan. Adapun kemaslahatan yang bersifat keutamaan (tahsiniyyah) adalah melakukan tindakan yang lain menurut adat dan menjauhi perbuatanperbuatan aib yang ditentang oleh akal sehat. Kemaslahatan ini merupakan keutamaan akhlak (Ali: 2016)

Akan tetapi, seharusnya maqashid syari'ah akan terus berkembang sesuai dengan tantangan zamannya, untuk memenuhi kebutuhan manusia akan setiap perkembangan tekhnologi ataupun kebutuhan manusia yang bersifat inovatif dan dinamis.

Perkembangan industri halal di Indonesia tidak terlepaskan dari tiga aspek penting, yaitu aspek produksi, distribusi dan konsumsi. Selain itu, ketiga aspek tersebut disertai dengan penggunaan tekhnologi yang semakin canggih dan inovatif sehingga perlu dikawal oleh sebuah aturan yang dalam hal ini hukum islam dalam kerangka maqashid syariah sehingga berimplikasi besar terhadap proses produksi, alat produksi, produk, pendistribusian serta pemilihan dalam aspek konsumsi masyarakat.

Dari aspek produksi yang diantaranya mencangkup konsep dan keselamatan kerja dalam industri halal dapat difahami sebagai berikut: 1. Dalam aspek landasan dalam industri halal yang diterapkan adalah landasan tauhid, sehingga bukan hanya mengetengahkan aspek keuntungan duniawi saja akan tetapi aspek akhirat menjadi bagian penyeimbangnya. Aspek keselamatan manusia, alam dalam aktivitas produksi dalam memproduksi produk halal -thayiban menjadi bagian konsentrasi industry halal dalam kerangka maqashid syariah. 2. Dalam aspek tujuan dalam industri halal bukan hanya memfokuskan pada keuntungan yang 
maximal saja, akan tetapi selain keuntungan ada juga tanggung jawab yang harus dipertimbangkan dalam proses ataupun hasilnya. Sehingga mencegah dan menolak segala kemadharatan dan kemafsadatan baik untuk manusia maupun alam sekitar, menjadi prioritasnya juga. 3. Dalam aspek pengupahan pekerja sesuai dengan usaha yang dilakukan dalam pekerjaannya, bahkan upah yang sesuai tersebut dalam kerangka maqashid syariah agar dapat diberikan sebelum keringat sang pekerja kering yang bertumpu pada kelaziman dalam mengupah. Selain itu, selain nilai materil juga dikembangkan konsep berkah dalam usaha industri halal.

\section{- Peranan Kemajuan Teknologi} terhadap Kemajuan Industri

Teknologi memgang peranan yang sangat penting dalam perkembangan industry dan ekonomi secara umum. Semua teori tentang perkembangan ekonomi, pasti memasukkan teknologi sebagai salah satu factor penting pertumbuhan. Teknologi adalah cara untuk mengolah atau menghasilkan suatu jenis barang atau jasa tertentu. Teknologi mempunyai hubungan dengan inovasi yaitu penemuanbaru yang telah diterapkan dalam proses produksi, seperti menemukan komoditi baru, menemukan cara produksi baru, danlain-lain.

Setidaknya ada tiga macam kemajuan teknologi yang sifatnya sederhana:

Pertama, kemejuan teknologi yang khusus meningkatkan efisiensi setiap unit tenaga kerja. Dengan kemjuan teknologi ini, seorang pekerja, dengan mesin atau alat yang sama, bisa meningkatkan outputnya. Perbaikan kesehatan dan ketrampilan termasuk kedalam kategori ini. Tenaga kerja yang bisa ditingkatkan produktifitasnya dengan kemajuan teknologi ini disebut tenaga kerja efektif.

Kedua, kemajuan teknologi yang meningkatkna produktifitas capital (mesin) tapi tidak mempengaruhi tenaga kerja. Dalam hal ini, setiap mesin dengan pekerja yang sama menghasilkan output yang lebih banyak atau lebih berkwalitas. Penggunaan bahan bakar yang lebih efisien adalah contoh dari kemajuan teknologi macam ini.

Ketiga, kemajuan teknologi yang mningkatkan produktifitas mesin dan tenaga kerja secar seimbang.

Kemajuan teknologi ini menggeser keatas seluruh fungsi produksi. Contoh dari kemajuan teknologi ini adalah perbaikan manajemen produksi yang meningkatkan produktifitas mesin 
maupun tenaga kerja secara

menyeluruh

Contoh paling jelas dari pengaruh

kemajuan teknologi pada

perkembangan industry adalah

perkembangan yang sangat cepat yang

terjadi pada industry elektronik dan

computer. Kalau pada masa lampau,

perkembangan satu teknologi

membutuhkan waktu beberapa tahun,

namun pada hari ini, perkembangan

yang sangat spektakuler pun bisa

terjadi hanya dalam hitungan bulan.

Namun kemajuan teknologi saja

ternyata tidak bisa dijadikan jaminan

kemajuan industry suatu masyarakat.

Yang harus dibangun terlebih dahulu

dan lebih utama adalah mentalitas

masyarakat dan etos kerjanya. Negara-

negara Amerika Latin yang telah

mengeluarkan dana yang sangat besar

untuk mengembangkan teknologi

industrinya, ternyata belum

menunjukkan kemajuan seperti yang

diharapkan, karena mentalitas

masyarakatnya belum banyak

mengalami perkembangan.

Dan kemajuan teknologi ternyata tidak selamanya menyenangkan. Kemajuan teknologi pada industry persenjataan contohnya. Perang Teluk tahun 1991, menyajikan pameran kecanggihan teknologi senjata pembunuh manusia.

Stealth aircraft, "Smart bombs,

antimissile missile, dan senjata-senjata

canggih lainnya, setiap hari

menyajikan drama pembantaian umat

umat manusia melalui teknologi

televisi yang bisa menyajikan gambar

berita tepat pada saat terjadinya

peristiwa.

Kemajuan teknologi sebagai basis

kemajuan industry ternyata harus

dibarengi dengan kemajuan mental

manusia yang akan mengoperasikan

teknologi tersebut.

- Perindustrian Dalam Perspektif

Islam

Islam, menurut para ulama,

menawarkan sebuah semangat dan

sikap mental agar setiap Muslim selalu berpandangan bahwa kehidupan hari esok harus lebih baik daripada hari ini dengan melalui aktivitas berkarya.

Sebagaimana firman Allah dalam AtTaubah [9]: 105

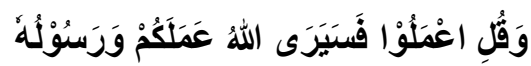

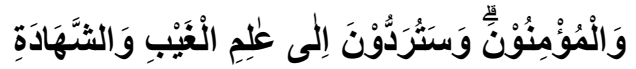

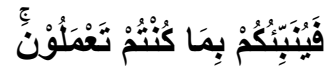

(Dan katakanlah: "Bekerjalah kamu, maka Allah dan Rasulnya serta orangorang beriman akan melihat pekerjaan itu, dan kamu akan dikembalikan 
kepada Allah yang mengetahui akan

yang ghaib dan yang nyata, lalu

diberitakan-Nya kepada kamu apa

yang -telah kamu kerjakan), dan

bahkan mendorong umat Islam untuk

menjadi 'Subjek Perubahan'

Islam selalu menyuruh umatnya untuk bekerja, apapun bentuk pekerjaan itu. Karena rahmat Allah akan diberikan kepada umat-Nya yang rajin bekerja. Hamba yang hidup sejahtera bahkan mampu membagi kesejahteraannya dengan orang lain, sangat terpuji dalam Islam. Islam juga mengecam umatnya yang malas bekerja. Bahkan seorang muslim yang miskin sangat dekat dengan kekufuran.

Usaha industry adalah salah satu bentuk pekerjaan yang sangat dihormati dalam Islam. Namun dalam berindustri, seorang muslim harus menepati aturan-aturan Islam, agar tidak menyimpang dari tujuan Islam. Lima prinsip seorang muslim dalam aktifitas ekonominya, yaitu: tauhid uluhiyyah, tauhid rububiyah, istikhlaf, tazkiyatu 1 nafs dan al-falah.

Maka aspek utama motivasi berindustri dalam Islam adalah:

1. Berdasarkan ide keadilan Islam sepenuhnya. Seorang pengusaha Islam tidal diizinkan untuk senantiasa mengejar keuntungan sematamata dengan alas an bahwa ia memiliki kemampuan untuk menegakkan keadilan dan kebajikan yang diingini oleh agama Islam. Permasalahan yang dihaadapi pengusaha sehubungan dengan rasionalitas ekonomi dan kehendak Islam adalah bahwa ia diharapkan akan bertindak untuk mendukung dan menguntungkan para konsumen disamping keuntungannya sendiri.

2. Berusaha membantu masyarakat dengan cara mempertimbangkan kemaslahatn orang lain pada saat seorang pengusaha membuat keputusan yang berkaitan dengan kebijaksanaan perusahaan.

3. Membatasi pemaksimuman keuntungan sesuai dengan batasbatas yang telah ditetapkan oleh prinsip diatas.

Tentang industry yang menyangkut kepentingan dan hajat masyarakat umum, Islam mengatur bahwa industry itu harus menjadi milik umum, tidak dikuasai pribadi. Seperti penjelasan hadits yang diriwayatkan oleh Abyadh bin Hamal:

“Bahwa dia meminta kepada Rasulullah untuk diberi hak mengelola tambang garam yang terdapat di daerah Ma'rab. 
Setelah dia pergi, Aqra' bin Habis

alTamimi bertanya: "Wahai Rasulullah,

pada zaman Jahiliyah saya mengambil

garam dari mana saja, Sesungguhnya

engkau telah memberikan sesuatu yang

bagaikan air mengalir (menyangkut

kebutuhan hidup orang banyak)". Maka

Rasulullah kemudian mengambil kembali

pemberian hak pengelolaan garam dari

Abyadh bin Hamal. Abyadh berkata:

"Saya berikan kembali tambang garam ini sebagai sadaqah dariku”. "Ya, tambang garam ini sadaqah darimu, saya ambil kembali karena tambang ini seperti air mengalir yang boleh diambil oleh siapa saja".

Pembahasan mengenai industry keil

- Manajemen dalam Industri Kecil Manajaemen adalah seni dan ilmu perencanaan, pengorganisasian, penyusunan, pengarahan dan pengawasan sumber daya untuk mencapai tujuan yang sudah ditetapkan. Sedangkan dalam industri kecil manajemen pengelolaan sangatlah dibutuhkan untuk kelancaran proses industri. Manajemen pngelolaan meliputi:

\section{$>$ Permodalan}

Pada dasarnya, dana atau atau modal yang dimiliki suatu industri digunakan untuk membiayai operasional kegiatan misalnya untuk membeli bahan dasar, bahan pembantu, membayar gaji para karyawan dan lain sebagainya. Dengan harapan melalui penjualan, perusahaan akan dapat memperoleh kembali dana yang telah dikeluarkan. Adapun modal dapat dibagi menjadi 2 yaitu: 3

- Menurut waktu pengeluaran modal

a. Modal investasi adalah modal yang digunakan dalam jangka panjang, namun dapat dipakai secara berulang kali. Biasanya dilakukan pada awal pendirian usaha tersebut. Seperti modal berupa tanah, bangunan, mesin, ataupun peralatan.

b. Modal kerja adalah modal yang akan digunakan untuk melakukan pendanaan terhadap biaya operasional dari usaha yang dijalankan. Modal kerja ini akan digunakan dalam jangka waktu yang lebih pendek.

- Menurut Sumber Dana

a. Modal sendiri, modal didapatkan dari pendanaan yang diperoleh dari diri 
sendiri. Misalnya pihak

pelaku usaha mendapatkan

modal dari harta kekayaan

sendiri.

b. Modal dari luar, modal dari luar ini diperoleh dari pihak luar dan bukan dari diri sendiri atau si pemilik usaha. Biasanya modal tersebut didapat dari bank, kerabat dekat, atau rekan bisnis.

Produksi

Produksi yang dalam bahasa inggris disebut production ialah suatu kegiatan mengenai pembuatan produk baik berupa fisik maupun berwujud jasa. Pengertian tersebut menjelaskan bahwa produksi adalah proses yang berkenaan dengan pengubahan bahan baku atau bahan dasar menjadi barang atau jasa.

Pemasaran

Pemasaran adalah suatu sistem total dari kegiatan bisnis yang dirancang untuk merencanakan, menentukan harga, mempromosikan dan mendistribusikan barang-barang yang dapat memuaskan keinginan dan jasa baik kepada para konsumen saat ini maupun konsumen potensial. Didalam pemasaran ada beberapa tahap yang harus diperhatikan diantaranya:
1. Memilih tujuan menetapkan harga Pertama-tama industri tersebut memutuskan dimana ingin memposisikan tawaran pasarnya. Semakin jelas tujuan suatu industri maka akan semakin mudah untuk menetapkan harga.

2. Menentukan permintaan Setiap harga akan menghasilkan tingkat permintaan yang berbeda dan hal ini mempunyai pengaruh yang berbeda terhadap tujuan pemasaran suatu industri.

3. Memperkirakan biaya Permintaan menentukan batas harga tertinggi yang dapat dikenakan suatu idustri untuk produknya. Biaya menentukan batas terendahnya. Industri tersebut ingin menetapkan harga yang menutupi biaya produksi, distribusi, dan penjualan produk, termasuk laba yang lumayan untuk upaya dan resikonya

- Manfaat Industri Kecil Industri kecil juga memberi manfaat sosial yang sangat berarti bagi perekonomian yaitu:

a. Terpenuhinya kebutuhan masyarakat, baik itu sandang, pangan, dan papan.

b. Terciptanya lapangan pekerjaan baru, semakin 
banyak jumlah industri yang

dibangun maka banyak pula

tenaga kerja yang diserap

terutama pada industri padat

karya.

c. Dapat meningkatkan

pendapatan perkapita

d. Dapat ikut serta mendukung

pembangunan nasional

dibidang ekonomi terutama

sector industry.

- Ciri-Ciri Industri Kecil

Ciri-ciri industri kecil menurut para

ahli sama dengan sector informal

adalah sebagai berikut:

a. Pendidikan formal yang rendah

b. Modal usaha sedikit

c. Upah rendah d. Kegiatan dalam skala kecil

Dengan melihat ciri-ciri diatas merupakan bukti bahwa industri kecil memperoleh pembinaanpembinaan demi meningkatkan produktivitas dan kualitas sehingga mampu bersaing dengan industri besar. 37 Berikut ini uraian karakteristik tentang industri kecil yang sering ditemui masyarakat yaitu sebagai berikut:

a. Pemilik merangkap manajer perusahaan yang bekerja sendiri dan

memiliki gaya manajemen

sendiri (merangkap semua

fungsi manajerial seperti

marketing, finance dan

administrasi).

b. Perusahaan keluarga, dimana pengelolanya mungkin tidak memiliki keahlian manajerial yang handal.

c. Sebagian besar membuat lapangan pekerjaan baru, inovasi, sumberdaya baru serta barang dan jasa-jasa baru.

d. Resiko usaha menjadi beban pemilik.

e. Pertumbuhan yang lambat, tidak teratur, terkadang cepat dan premature.

f. Fleksibel terhadap bentuk fluktuasi jangka pendek, namun tidak memiliki rencana jangka panjang.

g. Independen dalam penentuan harga produksi atas barang atau jasajasanya

h. Prosedur hukumnya sederhana.

i. Pajak relative ringan, karena yang dikenakan pajak adalah 
pribadi/pengusaha bukan

perusahaannya.

j. Komunikasi dengan pihak luar bersifat pribadi.

k. Mudah dalam proses pendiriannya. .

1. Mudah dibubarkan setiap saat jika dikehendaki.

m. Pemilik mengelola secara mandiri dan bebas waktu.

n. Pemilik menerima seluruh laba.

o. Umumnya mempunyai kecenderungan mampu untuk service.

p. Merupakan tipe usaha yang paling cocok untuk mengelola produk, jasa atau proyek perintisan yang sama sekali baru atau belum pernah ada yang mencobanya sehingga sedikit pesaing.

q. Terbukanya peluang dengan adanya berbagai kemudahan dalam peraturan dan kebijakan pemerintah yang mendukung berkembangnya usaha kecil di Indonesia.

r. Relatif tidak membutuhkan investasi yang terlalu besar, tenaga kerja yang tidak berpendidikan tinggi, serta sarana produksi lainnya yang tidak terlalu mahal.

- Peran Industri Kecil dalam Perekonomian

Tidak dapat dipungkiri bahwa industri kecil dan menengah memegang peranan penting dalam memajukan perekonomian suatu Negara. Demikian halnya dengan Indonesia, sejak diterpa badai krisis financial pada tahun 1996 silam, masih banyak usaha kecil menengah yang hingga saat ini masih mampu bertahan. Meskipun mereka sempat goyang oleh dampak yang ditimbulkan, namun dengan semangat dan jiwa yang kuat maka mereka secara perlahanlahan mampu bangkit dari keterpurukan. Hal inilah yang membedakan antara usaha-usaha kecil dan usaha besar, meskipun penghasilan yang diperoleh lebih besar namun resiko yang ditimbulkan akan lebih besar juga. Terdapat tiga alasan Indonesia harus mendorong industriindustri kecil agar dapat terus berkembang. Pertama, karena industri kecil cenderung memiliki kinerja yang lebih baik dalam hal menghasilkan tenaga kerja yang produktif. Kedua, seringkali mencapai 
peningkatan produktivitasnya

melalui investasi dan perubahan

teknologi. Hal ini merupakan

bagian dari dinamika usahanya

yang terus menyesuaikan

perkembangan zaman. Ketiga,

usaha kecil ternyata memiliki

keunggulan dalam hal fleksibilitas

dibandingkan dengan perubahan

besar.

Dalam hal ini peran industri kecil

dalam kegiatan ekonomi

masyarakat yaitu sebagai berikut:

a. Memiliki potensi yang besar dalam penyerapan tenaga kerja.

b. Memiliki kemampuan untuk memanfaatkan bahan baku lokal, memegang peranan utama dalam pengadaan produk dan jasa bagi masyarakat, dan secara langsung menunjang kegiatan usaha yang berskala lebih besar.

c. Industri kecil relative tidak memiliki utang dalam jumlah besar. d.

d. Industri kecil memberikan sumbangan kepada PDB nasional. e.

e. Dapat menumbuhkan usaha di daerah, yang mampu menyerap tenaga kerja.

f. Akhir-akhir ini peran industri kecil diharapkan sebagai salah satu sumber peningkatan

ekspor non migas.

\section{KESIMPULAN}

Istilah industri berasal dari bahasa latin, yaitu industria yang artinya buruh atau tenaga kerja. Istilah industri sering digunakan secara umum dan luas, yaitu semua kegiatan manusia untuk memenuhi kebutuhan hidupnya dalam rangka mencapai kesejahteraan.

Istilah industri berasal dari bahasa latin, yaitu industria yang artinya buruh atau tenaga kerja. Istilah industri sering digunakan secara umum dan luas, yaitu semua kegiatan manusia untuk memenuhi kebutuhan hidupnya dalam rangka mencapai kesejahteraan.

1. Industri kecil konveksi jilbab di Desa Pendosawalan berperan dalam (a) menciptakan lapangan pekerjaan dan menyerap tenaga kerja bagi masyarakat Desa Pendosawalan dan sekitarnya terutama ibu 
rumah tangga. (b)

meningktakan pendapatan

masyarakat Desa

Pendosawalan yang

awalnya tidak mempunyai

pendapatan sekarang dapat

membantu meningkatkan

ekonomi keluarga. (c)

meningkatkan

perekonomian masyarakat

karena yang dahulunya desa

tersebut adalah desa yang

banyak dengan

pengangguran dengan

tingkat kejahatan yang

tinggi sekarang sudah

berubah menjadi desa

sentra penghasil jilbab.

2. Peran industri kecil dalam

meningkatkan

perekonomian masyarakat

menurut perspektif Islam

bahwa Pemilik industri

kecil konveksi Jilbab sudah

melibatkan prinsip-prinsip

ekonomi Islam dalam usaha

mereka. Dimana industri

kecil konveksi jilbab

melibatkan prinsip

ketauhidan, prinsip 'adl,

prinsip jaminan sosial,

prinsip khilafah dan prinsip

ma'd akan tetapi peran

pemerintah dalam memberikan bantuan belum

menyeluruh kepada

masyarakat terutama

pemilik usaha konveksi

jilbab dan juga pemberian

jaminan sosial berupa BPJS

belum diterapkan dalam

usaha konveksi jilbab di

Desa Pendosawalan.

Pemahaman dan semangat

dalam mengaplikasikan

konsep halal dan thoyib

dalam ranah industri halal

di Indonesia seharusnya

memiliki semangat dan

motivasi dalam kerangka

maqashid syariah, sehingga

perkembangan industri

halal tersebut dapat sejalan

dengan tujuan utamanya

agar para konsumen di

Indonesia khususnya bagi

masyarakat muslim terjaga

dalam segala segi

pemenuhan kebutuhannya

yang dipenuhi kebutuhan

tersebut melalui industri

halal yang bersifat dinamis

dan inovatif, serta

senantiasa dalam rangka

menjaga kemaslahatan bagi

semua pihak. 


\section{DAFTAR PUSTAKA}

Al-Jurjanî, A. M.A. 1405.

Tahqîq Ibrâhîm alAbyarî.

Bayrût: Dâr al-Kitâb al-

'Arabî.

Ali, M. 2016. Konsep

Makanan Halal dalam

Tinjauan Syariah dan

Tanggung Jawab Produk

Atas Produsen Industri

Halal . Jurnal Al-Ahkam.

Vol.XVI, No. 2, Juli 2016.

Al- Syatibi. T.th. al-

Muwafaqat fi Ushul

alSyari'ah.

Kairo: Mustafa

Muhammad. Al-

Qaradhawi, Y. 2007. Fiqh

maqashid Syariah:Moderasi

Islam antara Aliran

Tekstual dan Aliran

Liberal. Jakarta: Pustaka

Al-Kautsar.

Abbas, Anwar. Bung Hatta

dan Ekonomi Islam, Jakarta

: Penerbit Buku Kompas,

2010 Ananda, Riski.

"Peran Home Indutsri

dalam Meningkatkan

Ekonomi Keluarga (Studi

Kasus Home Industri

Keripik di Kelurahan Kubu
Gadang )", JPM FISIP,

Vol.3, No.2

Oktober 2016 An-Nabani,

Taqiyuddin. Membangun

Sistem Ekonomi Alternative

Perspektif Islam, Surabaya :

Risalah Gusti, 1996

Arikunto, Suharsini.

Prosedur Penelitian Suatu

PendekatanPraktik, Jakarta

: Rineka Cipta, 2013

Azhary, Saleh Irzan.

Industri Kecil Sebuah

Tinjauan dan

Perbandingan, Jakarta :

LP3ES, 1986

Abd Aziz Islahi, Economic

Concept of Ibn Taimiyah,

(London: The Islamic

Foundation, 1988)

Abdurrahman al-Maliki,

Politik Ekonomi Islam,

(Bangil: al-Izzah, 2001)

A.L. Udovitch, The Islamic

Midle East 700-1900, (New

Jersey: The Darwin Press.

Inc., 1981) Boediono, Teori

Pertumbuhan Ekonomi,

(Yogyakarta: BPFE, 1981)

Cameron, Rondo, Lary

Neal, a Concise Economic

History of the World, (New

York: Oxford Unniversity

Press., 2003 
Chryssides GD, and Kaler

JH. (1993) An Introduction

to Business Ethics. London:

Chapman and Hall

Donaldson T. (1982).

Constructing a Social

Contract for Business. In:

Donaldson T. (Ed.)
Corporations and Morality. Englewood Cliffs: PrenticeHall Duska RF, and Clarke JJ. (2002) Ethical Issues in Financial Services. In: Bowie NE. (Ed.) The Blackwell Guide to Business Ethics. Blackwell: Oxford. 